DOI : $10.14746 /$ ps.2019.1.28

\title{
The United States and Poland after 1989, Kraków, 27 May, 2019
}

On May 27, 2019, in the Auditorium Maximus of the Jagiellonian University, a debate on the recent history of Polish-American relations took place. The Ambassadors of the USA to Poland Victor Ashe (2004-2009) and Stephen Mull (2012-2015) and Polish Ambassadors to the USA Janusz Reiter (2005-2007) and Maciej Kozłowski (1993-1995 as chargé d'affaires) took part in the discussion. The panel was moderated by TVN24 journalist Jacek Stawiski and hosted by the US Consulate General in Kraków and the Jagiellonian University.

The event started with an official welcoming by the Rector of the Jagiellonian University Prof. dr hab. med. Wojciech Nowak. The first question to the panelists concerned their personal memories about the breakthrough year of 1989. Mr. Mull remembered his first posting to Poland (1984-1986), during which he was asked to write a memo on whether the democratization of Poland was possible. Though he came to the conclusion that this would eventually happen, he absolutely did not expect it to happen so fast. Mr. Reiter stressed the fact that in 1989 the discussion in Poland was very much focused on the future of Germany. He had come to the conclusion then that relations with Germany and the USA were decisive for Poland's national security. In this context, he was worried that the fall of the Berlin Wall would shift the attention of the international community from Poland to Germany. Mr. Ashe spoke about the relevance of Poland as a topic of US domestic politics. He also pointed out that Lech Wałęsa's speech to Congress on November 15, 1989 marked the first appearance of a person not in public office in the US Congress. At the time, this was a clear message of US support for the region. Mr. Kozłowski added that the high level of recognition of John Paul II and Lech Wałęsa aroused the sympathies of the American public and their interest in Poland. Another crucial factor was also the young employees of the State Department, like Stephen Mull, who were curious about our region.

The next question concerned the panelists' outlook on the rapid change that then took place, and how the United States supported Poland on its road to democracy and NATO. Mr. Mull observed that in 1991 the Soviet Union still existed. This aroused concerns that too rapid change might end like the 'Carnival of Solidarity' in 1981. Therefore, the United States was very cautious in its contacts with Solidarity and the Polish United Workers' Party. The transformation speeded up after the Round Table talks. This process was supported by the United States, which in April 1989 established the Polish American Enterprise Fund, which was the first US support program to eventually generate profit. Mr. Kozłowski emphasized the importance of US moral support for the still small-scale opposition. Also the reduction of Poland's debt was a huge support which positively impacted the economic reforms of Leszek Balcerowicz. Mr. Ashe mentioned the fortunate election of George W. Bush as US President in 1988. Unlike many other US presidents, he already possessed experience in international politics when taking office. Mr. Reiter was of the same opinion, though he warned against retrospective determinism. Though President George W. Bush acted cautiously, he had a clearly defined goal: to prevent the rise of a neutral Germany in the center of Europe, since this would have meant the end of NATO and, by this token, the end of Central and Eastern European countries' dreams of freedom and democracy. Mr. Re- 
iter explained that, through Germany, Poland became a neighbor of the European Union and NATO, thus moving closer to both organizations. In the Ambassador's assessment, it would have been impossible for Poland to bypass a neutral Germany back then. Avoiding such a scenario was, in the opinion of Mr. Reiter, "a masterpiece of American diplomacy." Mr. Kozłowski spoke about the deep changes in the understanding of international politics after departing from the Nixon doctrine, which separated the world into spheres of influence, whereby certain security interests were considered legitimized (in the same way making others non-legitimized). This departure was not univocal, since voices could be heard in the United States that the Yalta system was stable and secure, while its alternatives were dangerous and could lead to unpredictable consequences.

Mr. Stawiski's next question concerned Poland in the grey zone of security in the 1990s. Back then, Poland consistently worked towards its accession to NATO, while serious doubts were aroused in the United States about extending the North Atlantic Alliance. Mr. Mull admitted that this topic was intensively discussed in the United States. One side argued that NATO was no longer needed, the other one warned that the dissolution of NATO might destabilize some states in Central and Eastern Europe. Weakening of the region might have led to a threat to international security in the future. An important part in convincing American politicians and society was played not only by Polish diplomats but also by the Polish-American community (Polonia). Mr. Ashe also pointed out that US support for NATO enlargement was still not certain in 1993. Though it was opposed by only a few, there were serious concerns about Russia's reaction. In this context, Polish Ambassador Jerzy Koźmiński played a major role. Knowing that politics is primarily local, he lobbied also outside Washington. This process took several years but ended in success. For Mr. Kozłowski, Poland's accession to NATO was one of the greatest successes of Polish diplomacy. In his opinion, the process was not only about the military and procedures, but also about a new way of thinking. In the context of the Polish lobbying campaign, he emphasized how important it was to gain allies in this matter. Convincing US decisionmakers and ordinary people was far more effective than propaganda, because compatriots are trusted far more.

The moderator's last question was about contemporary Polish-American relations and their future. The panelists recalled Richard Holbrooke, who said that the United States is a European power. In this sense, US commitment to Europe's security derives from a feeling of a community of values and interests. According to Mr. Stawiski, this is being questioned today, and it is a joint challenge to adapt this common core to today's circumstances. Mr. Mull observed that every success brings with it some risks. Today, Americans are tired of their global responsibilities, though he remains optimistic. He justified his optimism with the strong commitment of Polish and US societies to the values of freedom and democracy. Mr. Kozłowski approached this question differently, as he pointed out the competition between two concepts of US relations with the outside world. One is "America first," representing the isolationist tradition, while the other one is the Wilsonian tradition, described as realistic idealism. It argues that the United States can be free and safe only when the entire world is free. After WW2, this policy was discontinued, but it lived on in the idea of a "Europe whole and free." Addressing the big number of young people present at the debate, Mr. Ashe remarked that freedom and democracy depend on the engagement of people. He expressed his hope that young people will be socially active as much as possible, regardless of their political preferences. 
In the last part of the debate, the moderator presented questions from the audience. The first one concerned threats to Poland-US bilateral relations. According to Mr. Reiter, we have to remember that there are no good national solutions to complex problems. He warned that pursuing a path of anti-European, anti-German and anti-French sentiments leads straight to anti-American sentiments. In Mr. Reiter's opinion, Poland can be successful only within a successful EU, and the same goes for EU-US relations. Mr. Mull agreed that international cooperation needs to be deepened, because there is no single national solution. He was seconded by Mr. Kozłowski who argued that, in a more and more dangerous world, renationalization would take us right back to the nineteenth century. Only strong transatlantic ties can help different countries in facing today's challenges. Mr. Ashe stated that individual problems do not have to threaten the whole of a relationship. Asked by the former Polish Defense Minister, Bogdan Klich, about the emergence of a new security system after Crimea's occupation by Russia in 2014, the former ambassadors agreed that the current system has been merely modified. The American panelists especially stressed the US's commitment to NATO.

Martin WYCISK

Poznań 